\title{
POSVET V POČASTITEV 80. LETNICE PROF. DR. DARKA RADINJE
}

23. novembra 2007 je Oddelek za geografijo Filozofke fakultete Univerze v Ljubljani pod spretno organizacijsko taktirko dr. Metke Špes s sodelavci organiziral znanstveni posvet in okroglo mizo v počastitev osemdesetletnice rednega profesorja prof. dr. Darka Radinje pod naslovom Fizična in okoljska geografija v teoriji in praksi. Strokovno srečanje (in ekskurzija pod vodstvom slavljenca) naj bi po prvotnem programu bilo 19. septembra 2007 v Bohinju, vendar je hudo neurje posvet preprečilo.

Po nagovoru predstojnika (dr. Dejan Rebernik), celostno zasnovani predstavitvi bogatega znanstveno-raziskovanega in pedagoškega opusa jubilanta (dr. Franc Lovrenčak) in vabljenega predavanja o Pokrajini, krajini v luči Geografskega terminološkega slovarja akademika dr. Ivana Gamsa, so sledile zgoščene predstavitve ključnih ugotovitev številnih, vsebinsko raznovrstnih in kakovostnih prispevkov.

Dr. Blaž Repe je predstavil prispevke (A. Mihevc, U. Stepišnik s sodelavci, M. Breg, B. Erhatič, B. Komac in M. Zorn, B. Repe, A. Vovk Korže, D. Ogrin), ki so posegli v različna vsebinska polja fizične geografije v teoriji. Poročevalec dr. Karel Natek je povzel ključne ugotovitve prispevkov (J. Kunaver, K. Natek, M. Bricelj, M. Bat, M. Zorn, M. Gabrovec, M. Pavšek, M. Ogrin), ki so osvetlile vprašanja fizične geografije v praksi. Spodaj podpisani je predstavil dognanja avtorjev (K. Vintar Mally, I. Rejec Brancelj, D. Cigale, M. Špes, D. Plut) o problematiki okoljske geografije v teoriji, dr. Barbara Lampič pa prispevke (V. Brečko Grubar, E. Šterbenk s sodelavci, A. Smrekar, B. Lampič, I. Mrak) s področja okoljske geografije v praksi.

Po funkcijsko zasnovanih predstavitvah temeljnih ugotovitev in odprtih vprašanj prispevkov je sledila živahna, vsebinsko poglobljena in občasno strokovno polemična razprava. V razpravi je z sebi lastnim žarom in znanstveno svežino zavzeto sodeloval tudi slavljenec. V zaključkuje bilopodčrtana potreba o pogostejši, strokovno kritičniizmenjavi, dobronamerni prevetritvi geografskih spoznanj, ki bogatijo znanstveno-aplikativno potencial fizične in okoljske geografije. In seveda iskrena želja o zdravju in strokovni vitalnosti jubilanta. 